\title{
Bridging the Gap: Technology and Veteran Academic Success
}

\author{
David Cass \\ University of Colorado, Boulder \\ Shane Hammond \\ University of Massachusetts, Amherst
}

\begin{abstract}
This paper presents two unique yet confluent perspectives regarding the use of technology to support student veterans in college, and is meant to ignite discussion of the blending of high impact practices with technology to promote their academic success. The authors highlight the historical trends of student veterans in the academy and discuss the barriers to success for this unique population of students. Uvize — an online mentoring and advising platform for student veterans-is introduced, and preliminary results from three forward thinking institutions are discussed. This article further defines why student veterans are a special student population on our campuses and require unique services to support their overall academic success. Theoretical and pragmatic technology-based solutions for student veteran success are presented.
\end{abstract}

\section{Introduction}

The terrorist attacks of September 11, 2001 made an indelible mark on our nation's collective history. At the same time, the events of that day would ultimately awaken a conversation six decades in the making. The dialogue began with veterans returning from the battlefields of World War II. At its core, this historical and now contemporary conversation focuses on the intersection of higher education in the United States and the needs of returning veterans transitioning from wartime service to civilian life and seeking a college education. According to DiRamio and Jarvis (2011), the current generation of wartime student veterans should emulate the post-World War II generation of college students, entering the doors of higher education as well-trained adults who have made tremendous sacrifices for their country. Entrance into higher education can be highly complex with a variety of unclear steps and a path that is not necessarily direct or structured. The tremendous variability of enrollment factors in higher 
education present significant challenges to contemporary combat veterans (Elliott, Gonzalez, \& Larson, 2011; Hammond, 2015; Livingston, Havice, Cawthon, \& Fleming, 2011).

The veterans of Operation Enduring Freedom (OEF) and Operation Iraqi Freedom (OIF) present unique educational and cultural needs as they transition from the military to a civilian college environment (McBain, 2008). Many of these veterans have expressed frustration in the bureaucratic structure of higher education and the difficulty they have experienced navigating this structure upon their discharge and return to civilian life (O’Herrin, 2011; Cook \& Kim, 2009; Radford, 2009). It would appear that, as Olson (1973) stated, our system of higher education has reverted to a structure resembling its pre-World War II self, creating barriers to combat veterans similar to those which existed at the time of the first Servicemen's Readjustment Act of 1944. Contemporary recommendations for easing the transition of OEF and OIF student veterans from soldier to student have included: modified admissions practices, veteran student orientation, proper academic credit for military training and experience, transition services, opportunities to connect with veteran peers, dedicated advising and counseling, assistance with benefits navigation, professional development for faculty, and accommodations for physical and psychological disabilities (Ackerman et al., 2008; Ackerman \& DiRamio, 2009; Cook \& Kim, 2009; Herrmann et al., 2009; Persky \& Oliver, 2010; Radford, 2009; Steele et al., 2010).

Integration into the academic environment is critical for retention (Kuh, Curce, Shoup, Kinzie, \& Gonyea, 2008). Therefore, institutional commitments to providing the necessary technology-based student and academic support services to student veterans are critical to the transition of this student population to campus after the completion of their military service. This paper will discuss the related literature distinguishing wartime veterans as a unique group of students from the general student population, and provide an overview of the conception, design, and implementation of Uvize-an online platform aimed at supporting veteran success in college.

\section{Related Literature}

The academy has long struggled with the unique needs presented by student veterans upon their arrival to campus (McBain, Kim, Cook \& Snead, 2012). Titus (1944) said the complex relationships between veterans and universities would require an intimate, institutional understanding of veterans' needs if they were to be successful in college. Despite Titus's (1944) call to the academy, there appears to be a very notable lack of attention to the student veteran population in the higher education literature over the past half-century (Hammond, 2015). In fact, Ackerman, DiRamio, and Mitchell (2008) were among the first of scholarly voices to draw attention to the needs of student veterans returning to higher education from contemporary conflicts. This paucity of literature related to student veterans in higher education since World War II underscores the need for consideration of alternative means of academic support using online technologies.

The current conflicts in Iraq and Afghanistan have awakened an important conversation for student veterans. This renewed conversation, stretching across six decades of history, once again implores colleges and universities to take pause and consider the distinct population student combat veterans represent in higher education (Hammond, 2015). Although it is difficult to chronicle the educational experiences of a group so widely dispersed, we need to better understand the world that veterans face when trying to go to college (Herrmann, et al., 2009). The design and implementation of online methods of teaching and support provide new and innovative opportunities for this special population of students on our campuses.

For many veterans, the transition to college is the most difficult adjustment to be made when returning to civilian life (Ackerman et al., 2008). Unlike the clarity and direction provided to veterans during their military experiences, the move to civilian life is a complicated endeavor fraught with many complex and undefined decisions. Consequently, this population of students presents a unique set of needs that will continue to require the adequate education of faculty, staff, and student peers to ensure a positive transition for combat veterans. According to Herrmann et al. (2009), "approximately 65\% of the 
general population has had some college education and 29\% has obtained a Bachelor's degree or higher. In contrast, approximately $41 \%$ of veterans attend college with only $15 \%$ obtaining a Bachelor's degree or higher" (p. 7). McBain et al. (2012) found only 39\% of colleges with dedicated veteran support services (such as academic advising, personal counseling, and co-curricular programming) have programs to train faculty and staff on how to better assist veterans, while $59 \%$ of these institutions help veterans make the difficult transition from the battlefield to the classroom (p. 14). The unique needs of this distinct population of students as they prepare to transition from combat to college, and the importance of online technologies in this process warrant further discussion in the literature.

Student veterans require assistance with problems rarely encountered by other students at the institution (Herrmann et al., 2009). Multiple challenges facing veterans as they transition to college include: relearning study-skills, insomnia, increased stress, avoidance of public spaces, depression and Post Traumatic Stress Disorder (PTSD) (Ford, Northrup, \& Wiley, 2009). These factors pose potential barriers to a veteran's transition to college and overall persistence upon enrollment. According to a national survey, Student Veterans: A National Survey Exploring Psychological Symptoms and Suicide Risk (Lipka, 2011) conducted by the National Center for Veterans' Studies, nearly half of military veterans who are enrolled in college show significant symptoms of PTSD, a third suffer from severe anxiety, and a quarter experience severe depression. Almost half of those enrolled in college have contemplated suicide at some point, and 20 percent have planned to kill themselves (Lipka, 2011).

Twenty-five percent of veterans separating from the military are expected to enroll in college within two years (Hughes, 2011). Not since the Servicemen's Readjustment Act of 1944 have colleges and universities across the country seen such dramatic increases in student combat veteran enrollments. The National Survey of Student Engagement (2010) found that student combat veterans were predominantly male, older, enrolled part-time, more likely to transfer and take distance education courses and were considered first-generation college students. Returning veterans demonstrate many of the characteristics of non-traditional students, including having work and family responsibilities, a delayed entry to higher education and membership in the low to middle quartile of socioeconomic status (Brown \& Gross, 2011). Although veterans were found to be attending all types of institutions, they were more likely than non-veterans to attend public institutions and less likely to attend baccalaureate colleges of the arts and sciences or the most research intensive doctorate granting universities (NSSE, 2010, p.17).

According to the Department of Veterans Affairs, for-profit and community colleges continue to dominate the list of institutions veterans attend using their education benefits (Sewall, 2010) and the number of student veterans attending private elite colleges are sparse (Sander, 2013).

Similar to their counterparts from World War II, combat veterans from OEF and OIF enrolling in higher education tend to be more mature and motivated in their studies than the general student population (Ackerman et al., 2008; Brown, 2009; Brown \& Gross, 2011; Hammond, 2015); Herrmann, Raybeck, \& Roland, 2008; Mangan, 2009; Rumann \& Hamrick, 2010). However, there was a perceived lack of campus support found by first-year veterans in comparison to non-veterans (NSSE, 2010). Student veterans in particular, were found to have more family and work obligations, but spent the same amount of time studying as non-veterans. However, these same veterans were less academically engaged in deep approaches to learning and perceived lower levels of support from their campuses (NSSE, 2010, p. 18). This data underscores the need for alternative methods of instruction and academic support for student veterans, in particular online technologies that ease the burden of work and family obligations while enrolled.

Additionally, about one in five combat veterans in college reported having at least one disability, twice that of non-veterans (NSSE, 2010). Approximately one-third of combat veterans previously deployed are likely to be diagnosed with TBI, PTSD, or major depression and about five percent will report symptoms of all three conditions (Tanielian \& Jaycox, 2008). Given these diagnoses, it is likely that a large percentage of combat veterans transitioning to college in the future may present physical and 
emotional conditions such as TBI or PTSD and requiring unique support from other traditional-aged students (Shackelford, 2009). Students diagnosed with one or both of these conditions will undoubtedly struggle both in and out of the classroom and may be hesitant to self-identify these or other disabilities acquired during their military service (Shackelford, 2009). Consequently, these veterans who have served in combat situations present unique and unanticipated challenges for faculty, administrators and staff (Shackelford, 2009), calling on the higher education community to develop new and innovative methods of online academic mentorship, skills preparation and engagement.

\section{Discussion}

Mentorship and preparation are two of the most significant factors that impact student success. Studies show that mentorship increases student retention up to 20\% (Seneca College, 2009). Academic preparation can only be enhanced by mentorship and yet finding a way to combine mentorship and preparation evokes images of a veteran's director poring over spreadsheets trying to find perfect mentormatches and classroom time when all student veterans are available.

Camaraderie does not leave veterans' mindsets after they leave the service. Veterans come from a culture of "having each other's back"-this bond is a powerful starting point for peer mentorship. Ask 10 veterans if they would mind helping out a fellow veteran and you'll like get 10 "yes's.” Peer mentorship works when you start with a personal common bond and military service is an incredibly strong one. But there is a problem, veterans don't wear uniforms anymore and they don't spend much time (if ever) in their campus' veteran's center. Rather, they often work part-time jobs. They are husbands, wives, fathers, mothers and they are students. In other words they are really busy! Asking a veteran to come to campus and spend time with each other is a heavy request. But what if you could tap into each other in a matter of seconds and your commitment to helping your fellow veteran didn't require more than a few minutes at a time? This is the mission of Uvize-a virtual online veterans center.

While there is truly no complete substitute for in-person interaction, Uvize presents a hybrid model that combines in-person support with online options, maximizing the impact of college or university support staff. There are four ways in which Uvize supports student retention: (a) Online mentorship access (b) online preparation, (c) team and community building, and (d) skills and training. All four are deemed essential and symbiotic for a successful online program. Uvize is designed to embrace the necessary and valuable on-campus leadership of staff and students. The online veteran's community created by Uvize is essentially an intelligence or communications portal for managing a mentorship program and preparing students for academic success.

\section{Online Mentorship Access}

While one on one mentorship programs allow relationships to run deep, it's nearly impossible to find perfect mentor matches that meet the protégé's career, academic and personal needs for expertise (nor is one mentor always available). This is precisely why students seek less in-depth and shorter forms of interaction within our community of staff and peers. The greatest source of these mentorship interactions are the other veterans and supporters on any campus. Online options allow students to very quickly find the right community member who holds the expertise they need, when they need it.

Online options allow students to match with mentors via a variety of criteria or to filter mentors via certain characteristics (for example: academic major). Technology allows learners to crowd source, retain and organize advice from within their community. Picture a student veteran at a state university interested in a pre-medical pathway having direct access to veterans in the medical school. Also picture telling veteran medical students they can be a tremendous resource right from their iPad and only need to give a few minutes a week. These particular medical students want to help fellow veterans but are restricted by time and location. These micro-mentorship moments can be held and aggregated online and can augment in-person meetings. 
Uvize supports mentorship by providing each student participant with one-on-one, small group and community mentorship in a centralized location. Mentors consist of staff members, alumni, graduate students and peers (current students). Student veteran peers provide on-going mentorship based on their unique experiences in the military and college. For any academic challenge the individual student faces, Uvize will find a mentor who has also faced that challenge and/or a staff member with the expertise they need to overcome an obstacle. This is typically done in matter of seconds, leaving each student veteran feeling as though they are surrounding by a team of people - staff and peers - committed to their success as a college student.

\section{Online Preparation}

While other scholarly articles have discussed challenges facing the student veteran, one under examined theme is the viewpoint that military service can be a foundation for academic success if harnessed correctly. Most veterans have a deep-rooted respect for team culture and advanced training. The culture of team and training that is deeply ingrained in student veterans from their military service can be productively applied to college academics, promoting academic success and persistence to graduation.

The case for online academic skills preparation is the ability to reach a student before he or she starts school. Providing incoming students with skills training that they can utilize at their own pace before they arrive to college is akin to preparing for the SAT before the test (not during). Put simply, preparing student veterans before arrival to campus, using components of Uvize, lessens the shock of their transition from a military environment to college. Uvize supports academic preparation by providing an online curriculum that provides an education framework for collegiate academics based on the military background. Uvize's online college success/skills-based curriculum is designed to highlight the key differences in the educational environments (military vs. college) prior to beginning college. Each course is implemented using the Uvize platform in advance of the student veteran's arrival to campus, which is designed to resonate with their prior training and experiences in the military, thus reducing common stressors associated with the college environment.

\section{The Importance of Team and Community Building}

Why is the military so successful on every battlefield? Soldiers go to war as a team; there are no singular acts in the military. Soldiers with specific areas of expertise surround each other in the military. Teamwork and mentorship are built into military training, but they are largely absent in the university setting when considering a student veteran's transition to college and on-going enrollment. Student veterans often view leaving the team-centric military culture and finding success in the autonomous environment of college as an insurmountable challenge. So why not make college a team sport? There is already a team of veterans and supporters on campus surrounding the student, but they may be difficult to locate.

At a typical university, the veterans' staff consists of two individuals who serve as many as 1,000 veterans on campus. The knowledge and mentor network is already there, we just need to find ways to tap into it. Veterans in law school are ideal mentors for pre-law veterans. Advanced engineering majors have valuable program knowledge that can be shared with prospective engineering students. It is not possible for the veteran's services director, usually a retired officer, to be an expert in every career path. But a mentor network surrounding each student can serve as a valuable resource for academic, personal and professional development.

Uvize supports the team-centric culture by using Internet technology to build a network of mentors that never sleeps. Students and staff can benefit from the ability to quickly help each other from any location without coordinating schedules. While a physical veteran's center is important to building community, an online version of the community is much more accessible when needed and augments the challenges of education, work and family often met by student veterans while enrolled. 


\section{Skills and Training}

How is it that our troops are able to successfully repair aircraft, navigate tanks and manage a nuclear reactor on a submarine? The answer is simple: we teach them how to do it first. I was a helicopter pilot-I think a pretty good one-but if I'd tried to learn on my own, I would have failed. In the military, we first learn skills and then we apply them. Why are we waiting until veterans start school before we help them to succeed?

The average student veteran is 33 years old and hasn't studied for an academic test or written a paper in many years (American Council on Education, Dec 2013). Veterans are arriving to campus without the required academic skills. The style in which they learned their military skills is not applicable to college. We expect them to figure it out as they go. Imagine if you asked an active duty soldier to "just wait and figure it out when the mission begins." If we train for war during peacetime then why not put academic skills training online so veterans can train for success before school begins? Even better, do it in a manner so they can meet their new classmates and advisors. Now their skills are developed and a team is in place before school begins.

Utilizing Internet technology is a key ingredient to creating a veteran community on campus. Addressing the concept of skills training prior to campus arrival is something that can also be quickly implemented. Taking action is critical, colleges need to create a team of veteran mentors, make them constantly accessible and provide pre-enrollment academic training.

Uvize supports key skills by educating the student on skills needed for college that most likely were not necessary during their military training. Specific topics include collegiate study, test taking, time-management, paper writing and more. These skills are often rusty for veterans who have not only been outside of the academic environment for quite some time but also have been studying and learning in a much less analytical manner than will be required in college.

\section{Linking Conceptual Outcomes to Practice}

While outcomes data on Uvize is in its infancy, three forward looking universities, John Carroll, George Washington, and Duke University have taken the next step of linking our conceptual outcomes to practice, demonstrating the early successes of a Uvize online virtual veterans center for their student veteran populations. These three universities, John Carroll, George Washington, and Duke, recognized the inherent value of incorporating an online component into their comprehensive veterans' services and have implemented the Uvize model over the last 12 months. The following three brief case studies are presented as a means of illustrating the preliminary outcomes these institutions have identified after launching Uvize.

\section{John Carroll University}

John Carroll is the first college in the country to employ an Uvize online veteran's center. Graduation rate has not been a challenge for John Carroll as their track record is excellent and they report a greater than 90\% graduation rate. Engagement and mentorship of their student body however has been a challenge. Traditional veteran's centers see about a $10 \%$ engagement rate (Student Veterans of America). Engagement here is defined as having visited the veterans' center one time during the semester. John Carroll's online center has engaged $73 \%$ of their student veteran population. Engagement for an online center means the student has created a profile and logs in numerous times per week.

\section{George Washington University}

Located in the heart of our nation's capital, GW hosts over 1,000 student veterans eager to start their education. GW believes this robust student population can be a valuable support system for one another and that this will be attractive to future student veterans. One of GW's student veteran initiatives, called VALOR, holds the goal of reaching 2,000 student veterans in the next 
two years. GW can now grant community access online to any students considering GW. On the Uvize platform prospective students can now seek mentorship from current students. GW believes this will help the decision making process for prospective students.

\section{Duke University}

When student veteran leader, Logan Meh Laituri discovered his school didn't host a physical veterans center he connected with Uvize to build an online center. Duke hosts a myriad of graduate programs including business, medicine, and law. Via an online center, Duke's undergraduate students can be directly connected to graduate students in their field of interest. With no dedicated veterans advisor on campus, student veterans at Duke, led by Logan are supporting each other via mentorship.

\section{Conclusion}

A student veteran's perception of other students or their experiences on campus may often translate into frustration or distraction in the classroom or the campus environment (Hammond, 2015). Consequently, this may cause an inability to concentrate or self-isolation for veterans in a traditional brick and mortar educational setting. Degree completion and comprehensive support options for student veterans through an online modality such as Uvize or other platforms of engagement allow for an alternative academic experience, potentially decreasing any anxiety or challenges associated with learning and persistence in college.

Properly developed on-line methods of advising, peer support and mentorship provide the opportunity for a less distracting, productive learning environment and account for the competing priorities of work, family, medical care and education that many student veterans face after their discharge from military service. This timely and innovative approach to the complexity of college for student veterans allows for a learning environment that provides convenience and comfort to the student veteran while also promoting a continued connection to the college community. This reduces the likelihood of these students to self-isolate and avoid reaching out for the proper academic or peer support necessary for them to persist to degree completion.

\section{About the Authors}

Dr. Shane Hammond is a demonstrated scholar-practitioner in higher education with diverse experience in student affairs administration and leadership. Currently serving on the graduate faculty in Higher Education Leadership \& Management at the University of Massachusetts, Dr. Hammond has worked tirelessly to support the creation of model student veteran programs in the state of Massachusetts. His ongoing research of student veterans in higher education provides empirical insight into the identity of student veterans who have experienced combat.

Dave Cass the founder of Uvize, an education technology company with a focus on academic planning tools for student veterans. He is also an adjunct professor of business at the University of Colorado, Boulder and the author of The Strategic Student Veteran: "Successfully Transitioning from the Military to College Academics." Dave is a Navy Lieutenant Commander and helicopter pilot in both Operation Enduring Freedom and Operation Iraqi Freedom. 


\section{References}

Ackerman, R., DiRamio, D., \& Mitchell, R. L. (2008). From combat to campus: Voices of studentveterans. NASPA Journal, 45(1), 73-102. Retrieved from http://www.naspa.org/pubs/index.cfm

Ackerman, R., \& DiRamio, D. (2009). Transitions: Combat veterans as college students. New Directions for Student Services, 126, 5-14.

Brown, E. (2009). Colleges try to ease veterans' move from combat to classroom. The Washington Post. Retrieved from www.washingtonpost.com/wpdyn/content/article/2009/09/17/AR2009091704680

Brown, P. A., \& Gross, C. (2011). Serving those who have served: Managing veteran and military best practices. The Journal of Continuing Higher Education, 59(1) 45-49. doi: 10.1080/07377363.2011.544982.

Cook, B., \& Kim, Y. (2009, July). From soldier to student: easing the transition of service members on campus. Washington, DC: American Council on Education. Retrieved from http://www.aascu.org

DiRamio, D., \& Jarvis, K. (2011). Veterans in higher education: When Johnny and Jane come marching to campus. ASHE Higher Education Report, 37(3).

Elliott, M., Gonzalez, C., \& Larsen, B. (2011). U.S. military veterans transition to college: Combat, PTSD, and alienation on campus. Journal of Student Affairs Research and Practice, 48(3), 279296. Retrieved from http://journals.naspa.org/jsarp/vol48/iss3/art2/

Ford, D., Northrup, P., \& Wiley, L. (2009). Connections, partnerships, opportunities, and programs to enhance success for military students. New Directions for Student Services, 126, 61-70.

Hammond, S. (in press). Complex perceptions of identity: The experiences of combat veterans in community college. Community College Journal of Research and Practice.

Herrmann, D., Raybeck, D., \& Roland, W. (2008). College is for veterans too. Chronicle of Higher Education, 55(13), A99. Retrieved from http://chronicle.com.proxy.gw.wrlc.org/article/CollegeIs-for-Veterans-Too/31872/

Hughes, T. (2011, April 11). Vets go from combat to campus. USA Today. Retrieved from http://www.usatoday.com/news/education/2011-04-11-college-vets_N.htm

Kuh, G., Curce, T., Shoup, R., Kinzie, J., \& Gonyea, R. (2008). Unmasking the effects of student engagement on first-year college grades and persistence. The Journal of Higher Education, 79, 540-563.

Lipka, S. (2011). Half of student veterans have contemplated suicide, study shows. Chronicle of Higher Education. Retrieved from http://chronicle.com/article/half-of-student-veterans-have/12852

Livingston, W., Havice, P., Cawthon, T., \& Fleming, D. (2011). Coming home: Student veterans' articulation of college re-enrollment. Journal of Student Affairs Research and Practice, 48(3), 315-331. Retrieved from http://journals.naspa.org/jsarp/vol48/iss3/art4

Mangan, K. (2009). Colleges help veterans advance from combat to campus. Chronicle of Higher Education. Retrieved from http://chronicle.com/proxy.gw.wrlc.org/article/Colleges-HelpVeterans-Adva/48846

McBain, L., Kim, Y. M., Cook, B. J., \& Snead, K. M. (2012, July). From soldier to student II: Assessing campus programs for veterans and service members. Washington, DC: American Council on Education. Retrieved from https://www.aascu.org/WorkArea/DownloadAsset.aspx?id=5505 
McBain, L. (2008, Summer). When Johnny (or Janelle) comes marching home. Perspectives, Washington, DC: American Association of State Colleges and Universities. Retrieved from https://www.aascu.org/WorkArea/DownloadAsset.aspx?id=4996

National Survey of Student Engagement (2010). Annual results. Bloomington: Indiana University Center for Postsecondary Research.

O’Herrin, E. (2011). Enhancing veteran success in higher education. Association of American Colleges and Universities, 13(1). Retrieved from: http://www.aacu.org/peerreview/pr-wi11/prwi11_oherrin

Olson, K. W. (1973). The GI bill and higher education: Success and surprise. American Quarterly, 25(5), 596-610.

Persky, K. R., \& Oliver, D. E. (2010). Veterans coming home to community college: Linking research to practice. Community College Journal of Research and Practice, 35(1), 111-120. doi: 10.1080/10668926.2011.525184

Radford, A. W. (2009). Military service members and veterans in higher education: What the new GI bill may mean for postsecondary institutions. Washington, DC: American Council on Education Center for Policy Analysis and Lifelong Learning.

Rumann, C. B., \& Hamrick, F. A. (2010). Student veterans in transition: Reenrolling after war zone deployments. The Journal of Higher Education, 81(4), 431-58. doi: 10.1353/jhe.0.0103

Sander, L. (2013). Veterans tell elite colleges: We belong. Chronicle of Higher Education. Retrieved from http://chronicle.com/article/At-Elite-Colleges-a-Push-to/136459

Sewall, M. (2010). Veterans use new GI bill largely at for-profit and 2-year colleges. Chronicle of Higher Education, 56(38), A20-A21. Retrieved from http://chronicle.com/article/Veterans-Use-Benefitsof-Ne/65914/

Shackelford, A. L. (2009). Documenting the needs of student veterans with disabilities: Intersection roadblocks, solutions, and legal realities. Journal of Postsecondary Education and Disability, 22(1), 36-42.

Steele, J. L., Salcedo, N., \& Coley, J. (Eds.). (2010). Service members in school: Military veterans' experiences using the Post-9/11 GI Bill and pursuing postsecondary education. Washington, DC: American Council on Education.

Tanielian, T., \& Jaycox, L.H. (Eds.), (2008). Invisible wounds of war: Psychological and cognitive injuries, their consequences, and services to assist recovery. Santa Monica, CA: Rand. Titus, C. H. (1944). The university and the new veteran. The Journal of Higher Education, 15(2), 71-78, 116. 